\title{
Characterization of Monoclonal Antibodies against Bovine herpesvirus type 1 selected by Phage Display Technology
}

\section{Caracterização de Anticorpos Monoclonais reativos ao Herpesvírus bovino tipo 1 selecionados por Phage Display}

\author{
Greice Japolla ${ }^{1}$; Ana Flávia Batista Penido²; Greyciele Rodrigues Almeida \\ Luiz Artur Mendes Bataus ${ }^{4}$; Jair Pereira Cunha Junior ${ }^{5}$; Cristina Ribeiro'; \\ Sinji Borges Ferreira Tauhata ${ }^{4}$; Guilherme Rocha Lino de Souza ${ }^{4 *}$
}

\begin{abstract}
The specificity of monoclonal antibodies (mAbs) to desired targets makes these molecules suitable for therapeutic and diagnostic uses against a wide range of pathogens. Phage display antibody libraries offer one method by which mAbs can be selected for, without the use of conventional hybridoma technology. In this work, phage display technology was used to construct, select and characterize a combinatorial single chain fragment variable (scFv) antibody library against bovine herpesvirus type 1 (BoHV-1) from the immune repertoire of chickens immunized with the virus. In silico analysis of the hypervariable domains of the antibody heavy chains revealed a high frequency of scFv fragments with low variability, suggesting that selection had probably been carried out and favored by a few immunogenic viral antigens. The reactivity of the scFv fragments selected against BoHV-1 was demonstrated by PhageELISA. A significant increase in antibody reactivity to the target was observed after six rounds of library selection, showing its potential use as a molecule for BoHV-1 diagnosis. The strategy described here opens up a field for the use of phage display as a tool for selection of monoclonal antibodies that could be used for theranostic applications against infectious and parasitic diseases of veterinary interest.

Key words: Antibody engineering. BoHV-1. Diagnosis. ScFv library.
\end{abstract}

\section{Resumo}

A especificidade dos anticorpos monoclonais $(\mathrm{mAb})$ aos alvos desejados torna estas moléculas adequadas para uso em diagnóstico ou terapia de uma vasta gama de agentes patogênicos. Biblioteca de anticorpos apresentados em fagos filamentosos é uma metodologia para a produção de mAbs, podendo ser utilizada como alternativa à tecnologia de hibridoma convencional, tradicionalmente empregada para este fim. Neste trabalho, a tecnologia de Phage display foi usada para construir, selecionar e caracterizar uma biblioteca combinatorial de fragmentos de anticorpos de cadeia única ( $\mathrm{scFv}$ ) contra o Herpesvírus bovino tipo 1 (BoHV-1) a partir do repertório imune de galinhas imunizadas com o vírus. A análise in silico dos

\footnotetext{
${ }^{1}$ Discente de Doutorado, Programa de Pós-graduação em Ciência Animal, Escola de Veterinária e Zootecnia, Universidade Federal de Goiás, UFG, Goiânia, GO, Brasil. E-mail:greicejapolla@hotmail.com

${ }^{2}$ Pesquisadora, M.e, Instituto de Ciências Biológicas, Departamento de Bioquímica e Biologia Molecular, UFG, Goiânia, GO, Brasil. E-mail: anaflavia0510@gmail.com

3 Pesquisadora, Dra , Escola de Veterinária e Zootecnia, UFG, Goiânia, GO, Brasil. E-mail: greyci_almeid@hotmail.com

${ }^{4}$ Profs. Drs., Instituto de Ciências Biológicas, Departamento de Bioquímica e Biologia Molecular, UFG, Goiânia, GO, Brasil. E-mail: bataus@ufg.br; stauhata@gmail.com; grlino@gmail.com

5 Prof. Dr., Instituto de Ciências Biomédicas, Departamento de Imunologia, Universidade Federal de Uberlândia, UFU, Uberlândia, MG, Brasil. E-mail: jair.cunha.junior@gmail.com

${ }^{6}$ Pesquisadora, Dra , Departamento de Bioquímica e Biologia Molecular, UFG, Goiânia, GO, Brasil. E-mail: cris.lino@gmail,com

* Author for correspondence
} 
domínios hipervariáveis das cadeias pesadas dos anticorpos revelou uma alta frequência de fragmentos $\mathrm{scFv}$ com baixa variabilidade, sugerindo que a seleção foi provavelmente conduzida e favorecida por poucos antígenos virais mais imunogênicos. A reatividade dos fragmentos $\mathrm{scFv}$ selecionados contra BoHV-1 foi demonstrada por Fago-ELISA. Observou-se um aumento significativo da reatividade dos anticorpos após seis ciclos de seleção, evidenciando sua utilização como molécula para o diagnóstico de BoHV-1. A estratégia aqui descrita abre a possibilidade do uso da tecnologia de Phage display como ferramenta na seleção de anticorpos monoclonais com potencial uso tanto para o diagnóstico quanto para terapia de doenças infecciosas e/ou parasitárias de interesse veterinário.

Palavras-chave: Engenharia de anticorpos. BoHV-1. Diagnóstico. Biblioteca scFv.

The bovine herpesvirus type 1 (BoHV-1) is an etiologic agent associated with respiratory infections and reproductive disorders in cattle, including infectious bovine rhinotracheitis (IBR), infectious pustular vulvovaginitis (IPV), and balanoposthitis (ENGELS; ACKERMANN, 1996). These diseases levy a high socio-economic cost through their impact on animal production and are considered relevant in the international trade of animals and animal products (e.g., semen and embryos). They are therefore included in the Office International des Epizooties (OIE) - Listed diseases, infections and infestations in force in 2017 by the World Organization for Animal Health (OIE, 2017).

We demonstrate here the use of the antibody engineering strategy to construct a phage display library of combinatorial single chain $(\mathrm{scFv})$ antibodies, in order to isolate and characterize monoclonal antibodies against BoHV-1. Our approach was based on the use of chicken as a source of antibody variability (DAVIES et al., 1995). The amplification of genes that code for the immunoglobulin light and heavy chains of an immunized chicken is facilitated by the gene conversion event, in which the flanking regions of these gene segments are conserved, allowing the amplification of an entire animal immune repertoire using only two primer pairs in a PCR reaction (ANDRIS-WIDHOPF et al., 2000).

The present study was approved by the Committee on the Ethics of Animal Experiments of the Federal University of Goiás (protocol number 20/2012). The chicken immunization assay, cDNA synthesis, PCR, and cloning were performed as described by Barbas III et al. (2001). Four immunizations were carried out in 15-day intervals, using $500 \mu \mathrm{L}$ of a BoHV-1 suspension at a concentration of $10^{5,5}$ Tissue Culture Infective Dose $\left(\mathrm{TCID}_{50} \mathrm{~mL}^{-1}\right)$. First-strand cDNA was synthesized using the Access Quick RT-PCR kit (Promega, USA), with $5 \mu \mathrm{g}$ of total RNA isolated from chicken's spleen using TRIzol Reagent (Life Technologies, USA).

Figure 1 shows a graphic representation of the construction and screening of a $\mathrm{scFv}$ antibody library against BoHV-1. The gene-coding variable heavy chain $(\mathrm{VH})$ fragments were PCRamplified from cDNA using the sense primer AGATCTTCCGCCGTGACGTTGGACGAG3' (VH-F) and antisense primer TAGTGGAGGAGACGATGACTTCGGTCC3' (VH-R) with a flexible long linker. Similarly, the variable light chain (VL) fragments were amplified using the sense primer GGCCCTGACTCAGCCGTCCTCGGTGTC3' (VL-F) and antisense primer CTAGAGGACTGACCTAGGACGGTCAGG3' (VL-R) (BARBAS III et al., 2001). PCR was performed using a Taq high-fidelity polymerase (Life Technologies, USA) to amplify the target cDNA, using the following reaction conditions for both gene fragments: hot-start denaturation at $94{ }^{\circ} \mathrm{C}$ for $5 \mathrm{~min}$, followed by 30 cycles of denaturation at $94{ }^{\circ} \mathrm{C}$ for $45 \mathrm{~s}$, annealing at $56^{\circ} \mathrm{C}$ for $1 \mathrm{~min}$, and extension at $72{ }^{\circ} \mathrm{C}$ for $2 \mathrm{~min}$, with a final extension step at $72{ }^{\circ} \mathrm{C}$ for $10 \mathrm{~min}$.

The VH and VL amplicons were purified using the WizardSVGelCleanup-System(Promega,USA)and combined in an overlap PCR using the sense primer AGGTGGCCCAGGCGGCCCTGACTCAG3' (OL-F) and antisense primer 
GCTGGCCGGCCTGGCCACTAGTGGAGG3' (OL-R) (BARBAS III et al., 2001) (Fig. 1B). The PCR conditions were: hot start at $94{ }^{\circ} \mathrm{C}$ for 5 min, followed by 25 cycles of denaturation at 94 ${ }^{\circ} \mathrm{C}$ for $1 \mathrm{~min}$, annealing at $56{ }^{\circ} \mathrm{C}$ for $1 \mathrm{~min}$, and extension at $72{ }^{\circ} \mathrm{C}$ for $2 \mathrm{~min}$, followed by a final extension step at $72{ }^{\circ} \mathrm{C}$ for $10 \mathrm{~min}$. The overlap scFv was digested with SfiI restriction enzyme and cloned into the phagemid pComb3X expression vector, fused with gene III encoding capsid phage protein 3. The phagemid was used to transform E. coli XL1-Blue cells. The pComb3X vector lacks all of the genes required for replication and assembly of phage particles (Fig. 1C), therefore the screening of the library was enabled through the helper phage VCSM13 (Stratagene, USA) which provided the genes for the correct replication and assembly of phage proteins. Six rounds of selection (biopanning) were carried out for enrichment of the recombinant phages expressing the $\mathrm{scFv}$ antibody fragments against BoHV-1(Fig. 1D). Phagemids containing selected $\mathrm{scFv}$ fragments were isolated using a Qiaprep Spin Mini Kit (Qiagen Inc, USA) and sequenced (Fig. 1E)

The light and heavy chain gene fragments were amplified and visualized on an electrophoresis gel at $350 \mathrm{bp}$ and $450 \mathrm{bp}$ respectively, as expected (Fig. 1A). Similarly, the visualization of a band of approximately $800 \mathrm{bp}$ from the overlap reaction confirmed the presence of the $\mathrm{scFv}$ antibody fragment (Fig. 1B).

The sequencing of the variable heavy-chain domain of the most reactive anti-BoHV-1 $\mathrm{scFv}$ fragments revealed an immunodominance of six scFvs with a high frequency of complementary determinant regions. Approximately 83\% (Freq 20/24) of all sequences was attributed to only two distinct sequences (Fig.1E). Experimental and natural infection and vaccination demonstrated that the antibodies are triggered against virus envelope glycoproteins (env). $\mathrm{gB}, \mathrm{gC}, \mathrm{gD}$ and $\mathrm{gE}$ are the main envelope elicitor glycoproteins in BoHV1 infections (TIKOO et al., 1995) and have been used as antigens in many platforms for BoHV-1 control (GOGEV et al., 2002; KHATTAR et al., 2010; OLIVER et al., 2009). The glycoprotein B is considered the most conserved among members of the Herpesviridae family and plays an important role in viral replication and cell-to-cell spread (HELDWEIN; KRUMMENACHER, 2008; KAASHOEK et al., 1998).

Interestingly in this work, we demonstrated that several different sequences showed in complementarity-determining regions (CDRs) are compatible with a few immunogenic env proteins displayed on the virus surface. Owing to the $\mathrm{scFv}$ selection process having been conducted with an intact virus, presumably these reported virus glycoproteins were responsible for the immune response and, therefore, also drove the enrichment of $\mathrm{scFv}$ with low variability of CDRs clones through the six rounds of biopanning.

Several studies aimed at the selection of virus antigens with therapeutic potential have been performed with polyclonal antibodies (ALMEIDA et al., 2015; SANTOS et al., 2012). Based on the principle that immunogenic antigens may elicit a stronger antibody $(\mathrm{Ab})$ response, since they more frequently encounter the host immune system, the immunodominance reflected by a high frequency of $\mathrm{scFv}$ fragments with low variability, can be considered an important parameter for their use in the screening of antigens for the design of BoHV-1 vaccine.

Over six rounds of selection, the most reactive scFv clones were selected and amplified, increasing their affinity to the BoHV-1. To evaluate this reactivity/affinity, a phage-ELISA was performed as previously described (BARBAS III et al., 2001). Microtiter plates were coated with $100 \mu \mathrm{L}$ of the BoHV-1 $\left(10^{5,5} \mathrm{TCID}_{50} \mathrm{~mL}^{-1}\right)$ per well and assayed using a purified PEG-precipitated pool of scFv-phage library previously selected against BoHV-1 from the sixth round of selection. As a negative control, we used an MDBK cell culture in MEM medium (Minimum Essential Medium Eagle, Sigma-Aldrich, USA) without the virus. A blank control was used under the same conditions 
previously described, with the suppression of the $\mathrm{scFv}$ fragments. The reaction was developed by incubation with peroxidase-labeled mouse anti-M13 IgG (1:2000) (Santa Cruz Biotech., USA) and a final step of adding $0.03 \% \mathrm{H}_{2} \mathrm{O}_{2}$ and $1 \mathrm{mg}$ $\mathrm{ml}^{-1}$ of $o$-phenylenediamine. Statistical analysis was carried out using the GraphPad Prism 6 software. The data are presented as the mean \pm standard deviation, using analysis of variance followed by Tukey`s test. $\mathrm{P}$ values $<0.05$ were considered to indicate statistically significant differences.

Figure 1. Construction and screening of the anti-BoHV-1 scFv library. (A) PCR amplification of VH and VL; Lane 1, 100 bp MW ladder (Amresco, USA); Lanes 2 and 3, chicken's VH and VL amplicons, respectively. (B) Overlap PCR and scFv amplification; Lane 1, 100 bp MW ladder (Amresco, USA); Lane 2, scFv (800 bp) amplicon. (C) scFv fragment cloned in the expression vector pComb3X. (D) Library screening process for selection of phage clones (scFv) against BoHV-1 immobilized in a microtiter plate. (E) CDRs amino acid sequencing and frequency (Freq) of 24 clones. \#, amino acid residue numbers of each CDR.

\section{(A)}
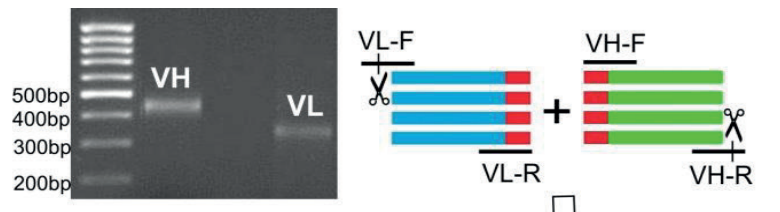

(B)

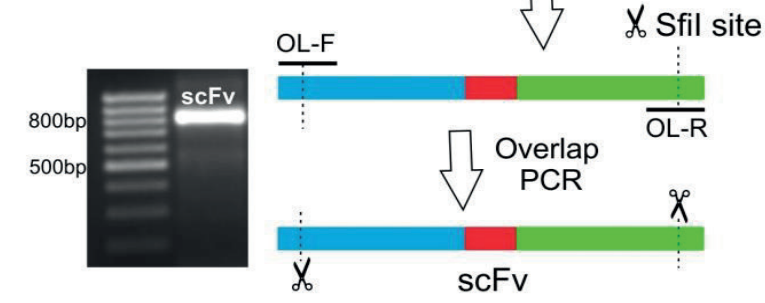

(C)

(D)
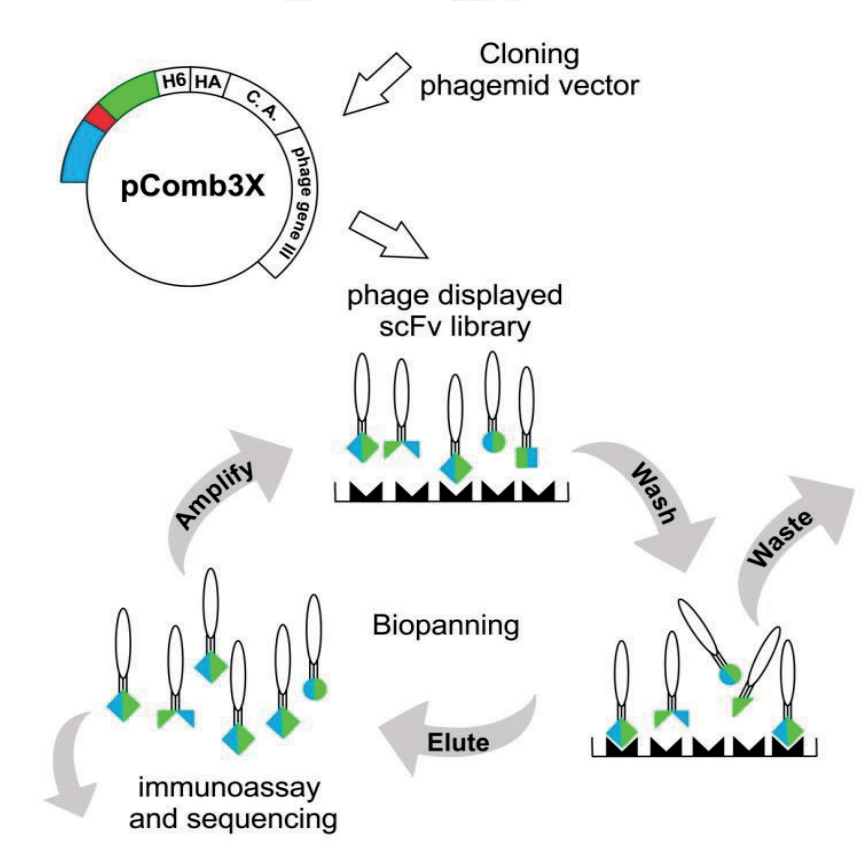

(E)

$\begin{array}{ccccccc}\text { CDR1 } & \# & \text { CDR2 } & \# & \text { CDR3 } & \# & \text { Freq } \\ \text { GFTFSSND } & 8 & \text { ISGSGSST } & 8 & \text { SGYVGYCGSGGACAGYMDT } & 19 & 10 / 24 \\ \text { GFTFSSFN } & 8 & \text { ISGDG-ST } & 7 & \text { SVDSDYYWITSGGG-IDA- } & 17 & 10 / 24 \\ \text { GFTFSSFN } & 8 & \text { I-GDG-ST } & 6 & \text { SVDSDYYWITSGSGGIDA- } & 18 & 1 / 24 \\ \text { GLTFSSND } & 8 & \text { ISGSGSST } & 8 & \text { SGYIAXVVAVAHVIITRT- } & 18 & 1 / 24 \\ \text { GFTFSSND } & 8 & \text { ISGSGSST } & 8 & \text { SLCWLLWRWRFVLVTWT-- } & 17 & 1 / 24 \\ \text { GFTFSSND } & 8 & \text { ISGSGSST } & 8 & \text { SGYVWLIWRWRLCWLHGHM } & 19 & 1 / 24\end{array}$


Figure 2 shows the differential reactivity of the $\mathrm{scFv}$ clones pool, which could discriminate BoHV1 (R6) from the negative $(\mathrm{NC})$ controls $(\mathrm{p}<0.05)$.

Despite the background observed in the negative control, possibly due to some cellular antigens present in the culture medium used for immunization of the experimental animals, a significant difference was observed when comparing the positive sample (virus in cell culture medium) and the negative sample (cell culture medium only). Consistent with our results, previous reports indicated that at the end of biopanning the ELISA reading obtained with antigens of interest is usually three or more times the reading of the negative controls (BARBAS III et al., 2001).

Aside from the possibility of using antibody fragments for passive immunization as an adjunctive disease prevention strategy against BoHV-1 (PASMAN et al., 2012), the selected scFv fragment displayed on the phage surface may provide useful reagents for theranostic applications in animal health. In this work, as the whole virus was used, the selected $\mathrm{scFv}$ fragments can be considered a set of poly-specific monoclonal antibodies. A differential specificity against the target can be achieved with monospecific antibodies selected in the biopanning process using purified specific antigens or different viral types in a differential selection. The choice of specific CDRs, unique to each viral type could be performed during DNA sequencing.

Starting with the diagnosis of BoHV-1 using different types of immunoassay, the strategy used here opens up a field of studies on antibody phage display to select monoclonal antibodies that can also be used as a tool for screening antigens (natural or synthetic) with the potential for vaccine design against a wide range of microorganisms of veterinary interest.

Figure 2. BoHV-1 reactivity of the scFv pool selected from antibody library. (R6), scFv from the sixth round of selection against BoHV-1 in cell culture; (NC), scFv from the sixth round of selection against cell culture without BoHV-1; (B), blank. (ANOVA with Tukey's multiple comparison test; *p $<0.05$ ).

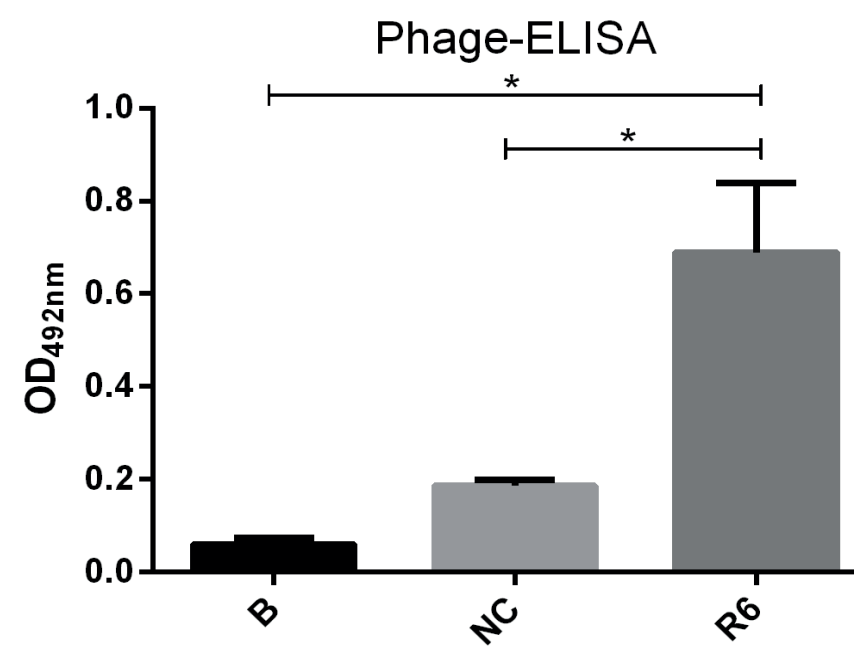




\section{Acknowledgments}

This work was supported by the Conselho Nacional de Desenvolvimento Científico e Tecnológico (CNPq); Coordenação de Aperfeiçoamento de Pessoal de Ensino superior (CAPES) and Fundação de Amparo à Pesquisa do Estado de Goiás (FAPEG).

\section{References}

ALMEIDA， G. R.; GOULART, L. R.; CUNHAJUNIOR, J. P.; BATAUS, L. A. M.; JAPOLLA. G.; BRITO, W M. E. D.; CAMPOS, I. T. N.; RIBEIRO, C.; SOUZA, G. R. L. A conformational epitope mapped in the bovine herpesvirus type 1 envelope glycoprotein $\mathrm{B}$ by phage display and the HSV-1 3D structure. Research in Veterinary Science, London, v. 101, p. 34-37, 2015.

ANDRIS-WIDHOPF, J.; RADER, C.; STEINBERGER, P.; FULLER, R.; BARBAS III, C. F. Methods for the generation of chicken monoclonal antibody fragments by phage display. Journal of Immunological Methods, New York, v. 242, n.1-2, p. 159-181, 2000.

BARBAS III, C. F.; BURTON, D. R.; SCOTT, J. K.; SILVERMAN, G. J. Phage display: a laboratory manual. New York: Cold Spring Harbor Laboratory Press, 200. $32 \mathrm{p}$.

DAVIES, E. L.; SMITH, J. S.; BIRKETT, C. R.; MANSER, J. M.; ANDERSON-DEAR, D. V.; YOUNG, J. R. Selection of specific phage-display antibodies using libraries derived from chicken immunoglobulin genes. Journal of immunological. Methods, New York, v. 186, n. 1, p. 125-135, 1995.

ENGELS, M.; ACKERMANN, M. Pathogenesis of ruminant herpesvirus infections. Veterinary Microbiology, Amsterdam, v. 53, n.1-2, p. 3-15, 1996.

GOGEV, S.; VANDERHEIJDEN, N.; LEMAIRE, M.; SCHYNTS, F.; D'OFFAY, J.; DEPREZ, I.; ADAM, M.; ELOIT, M.; THIRY, E. Induction of protective immunity to bovine herpesvirus type 1 in cattle by intranasal administration of replication-defective human adenovirus type 5 expressing glycoprotein $\mathrm{gC}$ or $\mathrm{gD}$. Vaccine, Guildford, v. 20, n. 9-10, p. 1451-1465, 2002.
HELDWEIN, E. E.; KRUMMENACHER, C. Entry of herpesviruses into mammalian cells. Cellular and Molecular Life Sciences, Basel, v. 65, n. 11, p. 16531668, 2008.

KAASHOEK, M. J.; RIJSEWIJK, F. A.; RUULS, R. C.; KEIL, G. M.; THIRY, E.; PASTORET, P. P.; VAN OIRSCHOT, J. T. Virulence, immunogenicity and reactivation of bovine herpesvirus 1mutantswith a deletion in the $\mathrm{gC}, \mathrm{gG}, \mathrm{gI}, \mathrm{gE}$, or in both the $\mathrm{gI}$ and $\mathrm{gE}$ gene. Vaccine, Guildford, v. 16, n. 8, p. 802-809, 1998.

KHATTAR, S. K.; COLLINS, P. L.; SAMAL, S. K. Immunization of cattle with recombinant Newcastle disease virus expressing bovine herpesvirus-1 (BHV-1) glycoprotein D induces mucosal and serum antibody responses and provides partial protection against BHV-1. Vaccine, Guildford, v. 28, n. 18, p. 3159-3170, 2010.

OLIVER, S. L.; SOMMER, M.; ZERBONI, L.; RAJAMANI, J.; GROSE, C.; ARVIN, A. M. Mutagenesis of Varicella-Zoster Virus glycoprotein b: putative fusion loop residues are essential for viral replication, and the furin cleavage motif contributes to pathogenesis in skin tissue in vivo. Journal of Virology, Irvine, v. 83, n. 15, p. 7495-7506, 2009.

PASMAN, Y.; NAGY, E.; KAUSHIKA, A. K. Enhanced bovine herpes virus type 1 neutralization by multimerized scFvs regardless of differential glycosylation. Clinical and Vaccine Immunology, Washington, v. 19, n. 8, p. 1150-1157, 2012.

SANTOS, E. M.; CARDOSO, R.; SOUZA, G. R.; GOULART, L. R.; HEINEMANN, M. B.; LEITE, R. C.; REIS, J. K. Selection of peptides for serological detection of equine infectious anemia. Genetic and Molecular Research, Ribeirão Preto, v. 11, n. 3, p. 2182-2199, 2012.

TIKOO, S. K.; CAMPOS, M.; BABIUK, L. A. Bovine herpesvirus 1 (BHV-1): biology, pathogenesis and control. Advances in Virus Research, New York, v. 45, p. 191-223, 1995.

WORLD ORGANISATION FOR ANIMAL HEALTH - OIE. Office International des Epizooties (OIE). OIEListed diseases, infections and infestations in force in 2017. Paris, 2017. Available at: <http://www.oie.int/en/ animal-health-in-the-world/oie-listed-diseases-2017/>. Accessed at: 13 abr. 2017. 